\title{
Zoogloea caeni sp. nov., a floc-forming bacterium isolated from activated sludge
}

\author{
Correspondence \\ Che Ok Jeon \\ cojeon@cau.ac.kr
}

\author{
Yongqi Shao, ${ }^{1}$ Bok Sil Chung, ${ }^{1,2}$ Seung Sik Lee, ${ }^{2}$ Woojun Park, ${ }^{3}$ \\ Sang-Suk Lee ${ }^{4}$ and Che Ok Jeon ${ }^{1}$
}

\author{
${ }^{1}$ Department of Life Science, Chung-Ang University, Seoul 156-756, Republic of Korea \\ ${ }^{2}$ Environmental Biotechnology National Core Research Center, Gyeongsang National University, \\ Jinju 660-701, Republic of Korea \\ ${ }^{3}$ Division of Environmental Science and Ecological Engineering, Korea University, Seoul 136-701, \\ Republic of Korea \\ ${ }^{4}$ Department of Animal Science and Technology, Sunchon National University, Sunchon 540-742, \\ Republic of Korea
}

Two floc-forming, nitrogen-fixing bacteria, strains EMB43 ${ }^{\top}$ and EMB61, obtained from activated sludge of a domestic wastewater treatment plant in Korea, were characterized. The two strains were very closely related, sharing $99.7 \% 16 \mathrm{~S}$ rRNA gene sequence similarity and showing a level of DNA-DNA relatedness of $93 \%$, which suggests that they represent members of a single species. Phylogenetic analysis based on 16S rRNA gene sequences showed that the two novel isolates formed a distinct phyletic lineage within the genus Zoogloea and were related most closely to Zoogloea resiniphila DhA-35 ${ }^{\top}$ and Zoogloea oryzae $A-7^{\top}$, with sequence similarities of $97.2 \%$. Levels of DNA-DNA relatedness between strain $\mathrm{EMB} 43^{\top}$ and Z. resiniphila $\mathrm{DhA}-35^{\top}$ and Z. oryzae $A-7^{\top}$ were 12.8 and $7.4 \%$, respectively. Cells of strains $E M B 43^{\top}$ and $E M B 61$ were facultatively aerobic, rod-shaped, Gram-negative and motile by means of a polar flagellum. The strains grew at temperatures of $15-40{ }^{\circ} \mathrm{C}$ (optimum: $25-30{ }^{\circ} \mathrm{C}$ ) and at $\mathrm{pH} 6.0-9.0$ (optimum: $\mathrm{pH}$ 6.5-7.5). The predominant fatty acids were $\mathrm{C}_{16: 0}, \mathrm{C}_{10: 0} 3-\mathrm{OH}$ and summed feature 3 $\left(\mathrm{C}_{16: 1} \omega 7 \mathrm{C}\right.$ and/or iso- $\left.\mathrm{C}_{15: 0} 2-\mathrm{OH}\right)$, and the predominant polar lipid was phosphatidylethanolamine. The genomic DNA G + C content was 64.9-65.0 mol\% and the major isoprenoid quinone was ubiquinone-8 (Q-8). On the basis of phenotypic, chemotaxonomic and molecular data, the isolates are considered to represent a novel species of the genus Zoogloea, for which the name Zoogloea caeni sp. nov. is proposed. The type strain is EMB $43^{\top}(=K C T C$ $22084^{\top}=$ DSM $19389^{\top}$ ).
Bacteria of the genus Zoogloea, a member of the family Rhodocyclaceae, are known to form characteristic cell aggregates embedded in gelatinous matrices, often called zoogloeal matrices (Dugan et al., 1992). Historically, the criteria used for taxonomic classification in this genus were based on phenotypic characteristics, which has resulted in confusion in identifying members of the genus and led to Zoogloea ramigera ATCC 25935 (=IAM 12670) being transferred to Duganella zoogloeoides based on molecular approaches (Hiraishi et al., 1997). At the time of writing,

The GenBank/EMBL/DDBJ accession numbers for the 16S rRNA gene sequences of strains $\mathrm{EMB}^{\mathrm{T}}{ }^{\mathrm{T}}$ and EMB61 are DQ413148 and DQ413150, respectively.

A transmission electron micrograph showing the general morphology of negatively stained cells of strain EMB43 ${ }^{\top}$, and a table detailing the cellular fatty acid compositions of strains $\mathrm{EMB} 3^{\top}$ and EMB61 and related species are available with the online version of this paper. the genus Zoogloea comprises three recognized species, namely Z. ramigera (Crabtree \& McCoy, 1967), Zoogloea resiniphila (Mohn et al., 1999) and Zoogloea oryzae (Xie \& Yokota, 2006).

Activated-sludge processes have been used to remove organic compounds as well as nutrients from wastewater, and insight into the bacterial communities is a prerequisite for understanding activated-sludge processes. Therefore, efforts have been made in our laboratory to isolate and characterize members of the bacterial community in activated sludge (Jeon et al., 2003; Lu et al., 2006; Park et al., 2007; Ryu et al., 2007). In the present study, we describe a novel species of the genus Zoogloea isolated from an activated-sludge process treating domestic sewage.

Strains EMB43 ${ }^{\mathrm{T}}$ and EMB61 were isolated from activated sludge of a domestic wastewater treatment plant in Pohang, 
Korea. The sludge sample was diluted serially with $1 \%$ (w/v) saline solution, spread on R2A agar (Difco) and incubated at $20{ }^{\circ} \mathrm{C}$ for 7 days for isolation of bacteria. Subcultivation was performed on R2A agar at $30{ }^{\circ} \mathrm{C}$ for 5 days.

Gram staining was performed by using a bioMérieux Gram stain kit according to the manufacturer's instructions. Cell morphology and motility were studied by using phasecontrast microscopy and transmission electron microscopy (JEM-1010; JEOL) as described previously (Jeon et al., 2005). Physiological characteristics of strains $\mathrm{EMB} 3^{\mathrm{T}}$ and EMB61 were examined by growing the isolates on R2A agar at different temperatures $\left(5-50{ }^{\circ} \mathrm{C}\right.$ at $5{ }^{\circ} \mathrm{C}$ intervals $)$ and in R2A broth adjusted to different $\mathrm{pH}$ values (5.0-10.0 at 0.5 $\mathrm{pH}$ unit intervals). $\mathrm{R} 2 \mathrm{~A}$ media with different $\mathrm{pH}$ values were prepared as described by Gomori (1955). The formation of flocs was determined by test-tube growth in R2A broth after 3 days incubation and was confirmed by examination with a phase-contrast microscope. Oxidase activity was tested based on oxidation of $1 \%(\mathrm{w} / \mathrm{v})$ tetramethyl-p-phenylenediamine (Merck) and catalase activity was evaluated based on production of oxygen bubbles in $3 \%(\mathrm{v} / \mathrm{v})$ aqueous hydrogen peroxide solution. Hydrolysis of casein, gelatin, Tweens 80 and 20, aesculin, urea, tyrosine, and starch was investigated on R2A agar according to the methods described by Lányí (1987) and Smibert \& Krieg (1994), and the results were read after 7 days at $30{ }^{\circ} \mathrm{C}$. Nitrate reduction was determined in R2A broth supplemented with $0.1 \%(\mathrm{w} / \mathrm{v}, 11.7 \mathrm{mM}) \mathrm{NaNO}_{3}$, which was incubated anaerobically in a GasPak jar at $30{ }^{\circ} \mathrm{C}$ for a maximum of 15 days. The concentrations of residual nitrate and any nitrite produced in broth media were determined by using an ICS-1000 ion chromatograph (DIONEX) according to the manufacturer's instructions. Growth under anaerobic conditions was determined on minimal medium agar (Stanier et al., 1966) containing $0.2 \%(\mathrm{w} / \mathrm{v})$ sodium acetate, and on R2A agar or R2A agar supplemented with $0.1 \%(\mathrm{w} / \mathrm{v}) \mathrm{NaNO}_{3}$ at $30{ }^{\circ} \mathrm{C}$ in a GasPak jar. For the minimal medium agar without $\mathrm{NaNO}_{3}$, ammonium chloride was used as a nitrogen source. Acid production from carbohydrates was tested as described by Leifson (1963) and additional enzyme activities and biochemical features were determined by using API ZYM and API 20NE kits at $30{ }^{\circ} \mathrm{C}$ as recommended by the manufacturer (bioMérieux).

Growth of strains EMB43 ${ }^{\mathrm{T}}$ and EMB61 was observed at temperatures of $15-40{ }^{\circ} \mathrm{C}$, with optimum growth at 25 $30{ }^{\circ} \mathrm{C}$. The strains grew at $\mathrm{pH} 6.0-9.0$, with optimum growth at $\mathrm{pH}$ 6.5-7.5. Fragmented portions of flocs and pellicles could be observed with the naked eye in test tubes when strains EMB43 ${ }^{\mathrm{T}}$ and EMB61 were incubated in R2A broth for 3 days. Formation of zoogloeal matrices was also identified by using phase-contrast microscopy. Flocs were formed at late growth stages and cells became embedded in gelatinous matrices to form zoogloeae, which were distinguished by a 'tree-like' morphology. All cells that were observed were rods (width, 0.6-0.9 $\mu \mathrm{m}$; length, 1.1-
$2.0 \mu \mathrm{m}$ ), motile by means of a polar flagellum (see Supplementary Fig. S1 in IJSEM Online). Strain EMB61 reduced nitrate to nitrogen gas rapidly without nitrite accumulation. However, because strain $\mathrm{EMB} 43^{\mathrm{T}}$ reduced nitrate to nitrite quickly, but reduced nitrite to nitrogen gas slowly, nitrite accumulation occurred in R2A broth media. Strains EMB43 ${ }^{\mathrm{T}}$ and EMB61 produced acid from several carbohydrates such as D-lactose, myo-inositol, D-galactose, D-mannitol and arbutin, results that could be used to differentiate these strains from recognized Zoogloea species. Anaerobic growth was not observed for 7 days at $30{ }^{\circ} \mathrm{C}$ either on minimal medium agar containing $0.2 \%(\mathrm{w} / \mathrm{v})$ sodium acetate or on R2A agar without the addition of nitrate, but small colonies were observed on R2A agar after 15 days incubation. However, in the presence of $0.1 \%$ $(\mathrm{w} / \mathrm{v})$ nitrate, small colonies were obtained after 7 days incubation both on R2A agar and on minimal medium agar containing $0.2 \%(\mathrm{w} / \mathrm{v})$ sodium acetate, indicating that denitrification contributed more to growth than to fermentation. Several phenotypic features of strains EMB $43^{\mathrm{T}}$ and EMB61 are presented and compared with those of related Zoogloea species in Table 1. Some phenotypic features of strains EMB43 ${ }^{\mathrm{T}}$ and EMB61, such as urease activity and utilization of glucose and mannitol, were different, which shows that the species represented by these two strains (see below) is metabolically diverse.

For analysis of fatty acid methyl esters, cells of strains $\mathrm{EMB} 43^{\mathrm{T}}$ and EMB61 were harvested from R2A agar plates after incubation for 3 days. Analysis of fatty acid methyl esters was performed according to the instructions of the Microbial Identification system (MIDI; Microbial ID, Inc.). Analyses of polar lipids and isoprenoid quinones were carried out by using the methods described by Komagata \& Suzuki (1987). The DNA G $+C$ content of strains EMB43 ${ }^{\text {T }}$ and EMB61 was determined by using a high-performance liquid chromatograph fitted with a reversed-phase column (GROM-SIL 100 ODS-2FE; GROM) according to the method of Tamaoka \& Komagata (1984). The major respiratory lipoquinone of strains $\mathrm{EMB} 43^{\mathrm{T}}$ and $\mathrm{EMB} 61$ was ubiquinone-8 (Q-8). The cellular membrane of strains EMB43 $^{\mathrm{T}}$ and EMB61 contained $\mathrm{C}_{16: 0}, \mathrm{C}_{10: 0} 3-\mathrm{OH}$ and summed feature $3\left(\mathrm{C}_{16: 1} \omega 7 c\right.$ and/or iso- $\left.\mathrm{C}_{15: 0} 2-\mathrm{OH}\right)$ as major fatty acids (see Supplementary Table S1, available in IJSEM Online). Polar lipids were dominated by a large amount of phosphatidylethanolamine, but a small amount of an amino group-containing lipid was also present. The DNA G + C contents of strains EMB $43^{\mathrm{T}}$ and EMB61 were 64.9 and $65.0 \mathrm{~mol} \%$, respectively. Strains $\mathrm{EMB} 43^{\mathrm{T}}$ and EMB61 were able to grow in nitrogen-free minimal broth medium (Stanier et al., 1966) containing 0.2\% $(\mathrm{w} / \mathrm{v})$ sodium acetate. PCR amplifications of the nifH gene by using the forward primer PolF, 5'TGCGAYCCSAARGCBGACTC- $3^{\prime}$, and the reverse primer PolR, 5'-ATSGCCATCATYTCRCCGGA-3' (Poly et al., 2001), on DNA extracted from strains $E M B 43^{T}$ and EMB61, Z. oryzae $\mathrm{A}-7^{\mathrm{T}}$, Z. resiniphila $\mathrm{DhA}-35^{\mathrm{T}}$ and $Z$. ramigera ATCC $19544^{\mathrm{T}}$ were carried out to confirm their 
Table 1. Characteristics of strains $E M B 43^{\top}$ and $E M B 61$ and related Zoogloea species

Strains: $1, \mathrm{EMB}_{3} 3^{\mathrm{T}}$ (data from the present study); 2, EMB61 (present study); 3, Z. resiniphila DhA- $35^{\mathrm{T}}$ (present study and Mohn et al., 1999); 4, Z. oryzae A-7 ${ }^{\mathrm{T}}$ (Xie \& Yokota, 2006); 5, Z. ramigera ATCC $19544^{\mathrm{T}}$ (Unz, 1984; Xie \& Yokota, 2006). Symbols: + , positive; - , negative; NA, data not available. All are positive for nitrate reduction.

\begin{tabular}{|c|c|c|c|c|c|}
\hline Characteristic & $1^{*}$ & $2^{*}$ & 3 & 4 & 5 \\
\hline Cell diameter $(\mu \mathrm{m})$ & $0.6-0.9$ & $0.6-0.9$ & $0.5-0.7$ & 1.0 & $1.0-1.2$ \\
\hline Growth at $45^{\circ} \mathrm{C}$ & - & - & $+^{*}$ & - & - \\
\hline Catalase & + & + & $-{ }^{*}$ & + & + \\
\hline Urease & - & + & $-{ }^{\star}$ & + & + \\
\hline Denitrification & $+($ slow $)$ & + (fast) & $-{ }^{\star}$ & + & + \\
\hline \multicolumn{6}{|l|}{ Hydrolysis of: } \\
\hline Gelatin & + & + & $+^{\star}$ & - & + \\
\hline Casein & - & - & $+^{*}$ & - & + \\
\hline \multicolumn{6}{|l|}{ Utilizes as sole carbon source: } \\
\hline Acetate & + & + & $+^{*}$ & - & + \\
\hline Citrate & - & - & $-{ }^{*}$ & - & + \\
\hline Glucose & + & - & $+^{*}$ & - & - \\
\hline Mannitol & - & + & $+^{*}$ & - & + \\
\hline DNA G $+\mathrm{C}$ content $(\mathrm{mol} \%)$ & 64.9 & 65.0 & NA & 65.1 & 65.3 \\
\hline
\end{tabular}

${ }^{\star}$ Data from the present study.

nitrogen-fixing capabilities. Expected PCR product sizes (about $340 \mathrm{bp)}$ of the nifH gene were detected for strains $\mathrm{EMB}_{3}{ }^{\mathrm{T}}, \mathrm{EMB} 61$ and $Z$. oryzea $\mathrm{A}-7^{\mathrm{T}}$, but not for $Z$. resiniphila DhA $-35^{\mathrm{T}}$ or $Z$. ramigera ATCC $19544^{\mathrm{T}}$ (data not shown). The predominant fatty acids, major lipoquinone and polar lipids, and DNA $\mathrm{G}+\mathrm{C}$ contents of strains $\mathrm{EMB}_{3}{ }^{\mathrm{T}}$ and EMB61 were in accordance with those of members of the genus Zoogloea (Unz, 1984; Mohn et al., 1999; Xie \& Yokota, 2006).

Sequencing of the 16S rRNA gene was carried out as described by Lane (1991). The resulting 16S rRNA gene sequences $(1460 \mathrm{nt})$ of strains $\mathrm{EMB} 43^{\mathrm{T}}$ and EMB61 were compared with available 16S rRNA gene sequences from GenBank by using the BLAST program (http:// www.ncbi.nlm.nih.gov/BLAST/) to determine an approximate phylogenetic affiliation, and gene sequences were aligned with those of closely related species by using the CLUSTAL W program (Thompson et al., 1994). Phylogenetic trees were constructed by using the neighbour-joining, maximum-likelihood and maximum-parsimony algorithms available in PHYLIP version 3.6 (Felsenstein, 2002). Sequence similarity values between the novel isolates and related strains were computed by using the FASTA3 program at EBI (http://www.ebi.ac.uk/fasta33/nucleotide.html). Bootstrap analysis was performed according to the algorithm of the Kimura two-parameter model (Kimura, 1980) of the neighbour-joining method in the PHYLIP package. DNADNA hybridization was carried out to evaluate the level of genomic DNA relatedness among the two novel isolates and closely related Zoogloea species by using the fluorometric microplate method (Ezaki et al., 1989). Fluorometric data recorded after $30 \mathrm{~min}$ reaction of the substrates were used for calculation of DNA-DNA hybridization values. The signals produced by self-hybridization were inferred as $100 \%$ and the levels of DNA-DNA relatedness were calculated from the mean values of five replications.

Phylogenetic analysis based on 16S rRNA gene sequences indicated that strains EMB43 ${ }^{\mathrm{T}}$ and EMB61 formed a distinct phyletic lineage within the genus Zoogloea (Fig. 1). The overall topology of the neighbour-joining tree was similar to that of the maximum-likelihood and maximumparsimony trees (data not shown). Comparative 16S rRNA gene sequence analysis revealed that strains $\mathrm{EMB} 43^{\mathrm{T}}$ and EMB61 were very closely related $(99.7 \%)$, and they showed a level of DNA-DNA relatedness of $93 \%$, which suggests that they represent members of a single species. Strains EMB43 ${ }^{\mathrm{T}}$ and EMB61 were related most closely to $Z$. oryzae $\mathrm{A}-7^{\mathrm{T}}, Z$. resiniphila $\mathrm{DhA}-35^{\mathrm{T}}$ and $Z$. ramigera ATCC $19544^{\mathrm{T}}$, with $16 \mathrm{~S}$ rRNA gene sequence similarities of 97.2 , 97.2 and $96.6 \%$, respectively. However, levels of DNADNA relatedness between strain EMB $43^{\mathrm{T}}$ and $Z$. resiniphila DhA $-35^{\mathrm{T}}$ and $Z$. oryzae $\mathrm{A}-7^{\mathrm{T}}$ were 12.8 and $7.4 \%$, respectively, which are clearly below the $70 \%$ threshold generally accepted for species delineation (Rosselló-Mora \& Amann, 2001; Stackebrandt et al., 2002). The physiological, biochemical and phylogenetic data presented suggest that strains EMB43 ${ }^{\mathrm{T}}$ and EMB61 represent a single novel species of the genus Zoogloea, for which the name Zoogloea caeni sp. nov. is proposed.

\section{Description of Zoogloea caeni sp. nov.}

Zoogloea caeni (cae' ni. L. gen. n. caeni of mud, referring to the isolation of the type strain from activated sludge).

Colonies on R2A agar are white, glistening, translucent, raised and circular with entire margins. Cells are facultatively 


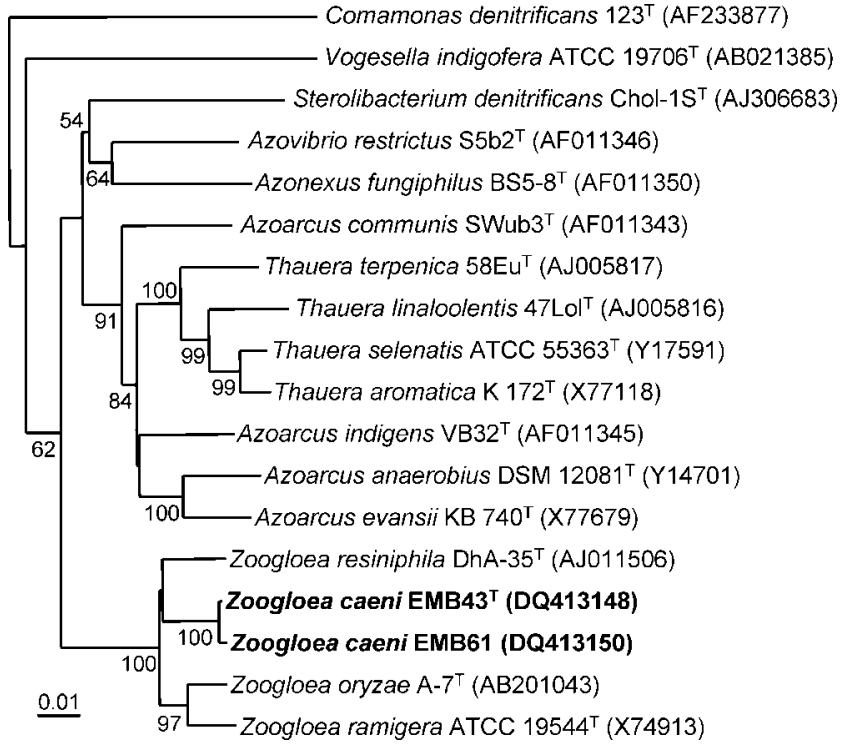

Fig. 1. Neighbour-joining tree based on 16S rRNA gene sequences showing the phylogenetic relationships between strains $E M B 43^{\top}$ and $E M B 61$ and related taxa. Bootstrap values are shown as percentages of 1000 replicates; only values $>50 \%$ are shown. Comamonas denitrificans $123^{\top}$ was used as an outgroup. Bar, 0.01 changes per nucleotide position.

aerobic, Gram-negative, short rods (about $0.6-0.9 \mu \mathrm{m}$ wide and $1.1-2.0 \mu \mathrm{m}$ long) that are motile by means of a polar flagellum. Positive for nitrate reduction to nitrogen gas and for nitrogen fixation. Growth occurs optimally at $25-30{ }^{\circ} \mathrm{C}$ and $\mathrm{pH}$ 6.5-7.5. Catalase- and oxidase-positive. Hydrolyses Tween 20 and gelatin, but not tyrosine, aesculin, casein, Tween 80 or starch. Produces acid from D-lactose, myoinositol, D-galactose, D-mannitol and arbutin, but not from raffinose, L-arabinose, melibiose, D-glucose, D-fructose, Dmannose or salicin. Negative for indole production and arginine dihydrolase activity. Negative for assimilation of Larabinose, $\mathrm{N}$-acetylglucosamine, maltose, D-mannose, potassium gluconate, capric acid, adipic acid, malic acid, trisodium citrate and phenylacetic acid (API 20NE). Produces alkaline phosphatase, esterase (C4), esterase lipase (C8), leucine arylamidase and naphthol-AS-BI-phosphohydrolase, but not lipase (C14), cystine arylamidase, trypsin, $\alpha$-chymotrypsin, $\alpha$-galactosidase, $\beta$-galactosidase, $\beta$-glucuronidase, $\alpha$-glucosidase, $\beta$-glucosidase, $N$-acetyl- $\beta$-glucosaminidase, $\alpha$-mannosidase or $\alpha$-fucosidase. Weak enzymic activities are observed for valine arylamidase and acid phosphatase. Contains a large amount of phosphatidylethanolamine as the major polar lipid. The major isoprenoid quinone is ubiquinone- $8(\mathrm{Q}-8)$. The major fatty acids are $\mathrm{C}_{16: 0}, \mathrm{C}_{10: 0} 3-\mathrm{OH}$ and summed feature $3\left(\mathrm{C}_{16: 1} \omega 7 \mathrm{c}\right.$ and/or iso- $\mathrm{C}_{15: 0}$ 2-OH). The DNA $\mathrm{G}+\mathrm{C}$ content is 64.9$65.0 \mathrm{~mol} \%$ (HPLC).

The type strain, EMB43 ${ }^{\mathrm{T}}\left(=\right.$ KCTC $22084^{\mathrm{T}}=$ DSM $\left.19389^{\mathrm{T}}\right)$, was isolated from activated sludge of a domestic waste- water treatment plant. EMB61 is a second strain of the species.

\section{Acknowledgements}

These studies were supported by grants from the MOST/KOSEF to the Environmental Biotechnology National Core Research Center (grant no. R15-2003-012-02002-0) and to the 21C Frontier Microbial Genomics and Application Center Program (grant no. MG05-0104-40 ), Ministry of Science and Technology, Korea.

\section{References}

Crabtree, K. \& McCoy, E. (1967). Zoogloea ramigera Itzigsohn, identification and description. Request for an opinion as to the status of the generic name Zoogloea. Int J Syst Bacteriol 17, 1-10.

Dugan, P. R., Stoner, D. L. \& Pickrum, H. M. (1992). The genus Zoogloea. In The Prokaryotes, 2nd edn, pp. 3952-3964. Edited by A. Balows, H. G. Trüper, M. Dworkin, W. Harder \& K.-H. Schleifer. New York: Springer.

Ezaki, T., Hashimoto, Y. \& Yabuuchi, E. (1989). Fluorometric deoxyribonucleic acid-deoxyribonucleic acid hybridization in microdilution wells as an alternative to membrane filter hybridization in which radioisotopes are used to determine genetic relatedness among bacterial strains. Int J Syst Bacteriol 39, 224-229.

Felsenstein, J. (2002). PHYLIP (phylogeny inference package), version 3.6a. Distributed by the author. Department of Genome Sciences, University of Washington, Seattle, USA.

Gomori, G. (1955). Preparation of buffers for use in enzyme studies. Methods Enzymol 1, 138-146.

Hiraishi, A., Shin, Y. K. \& Sugiyama, J. (1997). Proposal to reclassify Zoogloea ramigera IAM 12670 (P. R. Dugan 115) as Duganella zoogloeoides gen. nov., sp. nov. Int J Syst Bacteriol 47, 1249-1252.

Jeon, C. O., Lee, D. S. \& Park, J. M. (2003). Microbial communities in activated sludge performing enhanced biological phosphorus removal in a sequencing batch reactor. Water Res 37, 2195-2205.

Jeon, C. O., Lim, J. M., Lee, J. M., Xu, L. H., Jiang, C. L. \& Kim, C. J. (2005). Reclassification of Bacillus haloalkaliphilus Fritze 1996 as Alkalibacillus haloalkaliphilus gen. nov., comb. nov. and the description of Alkalibacillus salilacus sp. nov., a novel halophilic bacterium isolated from a salt lake in China. Int J Syst Evol Microbiol 55, 1891-1896.

Kimura, M. (1980). A simple method for estimating evolutionary rates of base substitutions through comparative studies of nucleotide sequences. J Mol Evol 16, 111-120.

Komagata, K. \& Suzuki, K. (1987). Lipid and cell-wall analysis in bacterial systematics. Methods Microbiol 19, 161-207.

Lane, D. J. (1991). 16S/23S rRNA sequencing. In Nucleic Acid Techniques in Bacterial Systematics, pp. 115-175. Edited by E. Stackebrandt \& M. Goodfellow. Chichester: Wiley.

Lányi, B. (1987). Classical and rapid identification methods for medically important bacteria. Methods Microbiol 19, 1-67.

Leifson, E. (1963). Determination of carbohydrate metabolism of marine bacteria. J Bacteriol 85, 1183-1184.

Lu, S., Park, M., Ro, H.-S., Lee, D. S., Park, W. \& Jeon, C. O. (2006). Analysis of microbial communities using culture-dependent and culture-independent approaches in an anaerobic/aerobic SBR reactor. J Microbiol 44, 155-161.

Mohn, W. W., Wilson, A. E., Bicho, P. \& Moore, E. R. B. (1999). Physiological and phylogenetic diversity of bacteria growing on resin acids. Syst Appl Microbiol 22, 68-78. 
Park, M., Ryu, S. H., Vu, T. H., Ro, H. S., Yun, P. Y. \& Jeon, C. O. (2007). Flavobacterium defluvii sp. nov., isolated from activated sludge. Int J Syst Evol Microbiol 57, 233-237.

Poly, F., Monrozier, L. J. \& Bally, R. (2001). Improvement in the RFLP procedure for studying the diversity of nifH genes in communities of nitrogen fixers in soil. Res Microbiol 152, 95-103.

Rosselló-Mora, R. \& Amann, R. (2001). The species concept for prokaryotes. FEMS Microbiol Rev 25, 39-67.

Ryu, S. H., Park, M., Jeon, Y., Lee, J. R., Park, W. \& Jeon, C. O. (2007). Flavobacterium filum sp. nov., isolated from a wastewater treatment plant in Korea. Int J Syst Evol Microbiol 57, 2026-2030.

Smibert, R. M. \& Krieg, N. R. (1994). Phenotypic characterization. In Methods for General and Molecular Bacteriology, pp. 607-654. Edited by P. Gerhardt, R. G. E. Murray, W. A. Wood \& N. R. Krieg. Washington, DC: American Society for Microbiology.

Stackebrandt, E., Frederiksen, W., Garrity, G. M., Grimont, P. A., Kampfer, P., Maiden, M. C., Nesme, X., Rossello-Mora, R., Swings, J. $\&$ other authors (2002). Report of the ad hoc committee for the re-evaluation of the species definition in bacteriology. Int J Syst Evol Microbiol 52, 1043-1047.

Stanier, R. Y., Palleroni, N. J. \& Doudorhoff, M. (1966). The aerobic pseudomonads: a taxonomic study. J Gen Microbiol 43, 159-271.

Tamaoka, J. \& Komagata, K. (1984). Determination of DNA base composition by reversed-phase high-performance liquid chromatography. FEMS Microbiol Lett 25, 125-128.

Thompson, J. D., Higgins, D. G. \& Gibson, T. J. (1994). ClusTAL W: improving the sensitivity of progressive multiple sequence alignment through sequence weighting, position-specific gap penalties and weight matrix choice. Nucleic Acids Res 22, 4673-4680.

Unz, R. F. (1984). Genus IV. Zoogloea Itzigsohn 1868, 30 ${ }^{\mathrm{AL}}$. In Bergey's Manual of Systematic Bacteriology, vol. 1, pp. 214-219. Edited by N. R. Krieg \& J. G. Holt. Baltimore: Williams \& Wilkins.

Xie, C. H. \& Yokota, A. (2006). Zoogloea oryzae sp. nov., a nitrogenfixing bacterium isolated from rice paddy soil, and reclassification of the strain ATCC 19623 as Crabtreella saccharophila gen. nov., sp. nov. Int J Syst Evol Microbiol 56, 619-624. 